\title{
Activation and immobilization of phenol-degrading bacteria on oil palm residues for enhancing phenols degradation in treated palm oil mill effluent
}

\author{
Panida Tosu ${ }^{1}$, Ekawan Luepromchai ${ }^{2}$, Oramas Suttinun ${ }^{1,3^{\dagger}}$ \\ ${ }^{1}$ Environmental Biotechnology Research Unit, Faculty of Environmental Management, Prince of Songkla University, Songkhla 90112, Thailand \\ ${ }^{2}$ Department of Microbiology, Faculty of Science, Chulalongkorn University, Bangkok 10330, Thailand \\ ${ }^{3}$ Center of Excellence on Hazardous Substance Management (HSM), Bangkok 10330, Thailand
}

\begin{abstract}
The presence of phenols in treated palm oil mill effluent (POME) is an environmental concern due to their phytotoxicity and antimicrobial activity. In this study, phenol-degrading bacteria, Methylobacterium sp. NP3 and Acinetobacter sp. PK1 were immobilized on oil palm empty fruit bunches (EFBs) for removal of phenols in the treated POME. The bacterial exopolysaccharides (EPS) were responsible for cell adhesion to the EFBs during the immobilization process. These immobilized bacteria could effectively remove up to 5,000 $\mathrm{mg} / \mathrm{L}$ phenol in a carbon free mineral medium (CFMM) with a greater degradation efficiency and rate than that with suspended bacteria. To increase the efficiency of the immobilized bacteria, three approaches, namely activation, acclimation, and combined activation and acclimation were applied. The most convenient and efficient strategy was found when the immobilized bacteria were activated in a CFMM containing phenol for $24 \mathrm{~h}$ before biotreatment of the treated POME. These activated immobilized bacteria were able to remove about $63.4 \%$ of $33 \mathrm{mg} / \mathrm{L}$ phenols in the treated POME, while non-activated and/or acclimated immobilized bacteria could degrade only $35.0 \%$. The activated immobilized bacteria could be effectively reused for at least ten application cycles and stored for 4 weeks at $4^{\circ} \mathrm{C}$ with the similar activities. In addition, the utilization of the abundant EFBs gives value-added to the palm oil mill wastes and is environmentally friendly thus making it is attractive for practical application.
\end{abstract}

Keywords: Immobilized bacteria, Oil palm residues, Palm oil mill effluent, Phenols, Phenols-degrading bacteria

\section{Introduction}

Palm oil is one of the major vegetable oils and a raw material for biofuel production. The largest palm oil producers are mainly in South East Asia, namely Malaysia, Indonesia and Thailand [1]. During process of wet palm oil extraction, large quantities of solid residues and wastewater are produced. Oil palm empty fruit bunches (EFBs) are among the most abundant residues obtained after the palm fruits are separated from the bunches for oil extraction. In Thailand, approximately EFBs of $9.0 \times 10^{5}$ ton/year are produced. However, only small amounts of EFBs are utilized as fuel and fertilizer in the palm oil mills and plantations, while most of them are left as waste [2]. Moreover, about 5-7.5 tones of water are used for 1 ton of crude palm oil production and more than $50 \%$ of the water used results in palm oil mill effluent (POME) [3].
POME generally contains high organic content and phenols which are responsible for the recalcitrant dark brown color of wastewater. Phenols are a group of substances commonly found in palm fruits. Alam et al. [4] and Cordova-Rosa et al. [5] reported that more than $1,000 \mathrm{mg} / \mathrm{L}$ phenols were present in POME. The most common conventional methods used for the treatment of POME are anaerobic digestion and/or anaerobic ponding systems [6, 7]. However, these methods are not effective in eliminating phenols to meet the regulatory standard required. This is because these compounds exhibit inhibitory effects on microorganisms and are not easily degraded [8-11]. Phenols cause serious health effects and are potentially toxic to living organisms in the environment [10, 12-13]. In addition, the contamination of phenols in water can lead to the formation of substituted compounds during disinfection process which increases taste and odor in the water supply [14]. Thus, the treated POME requires further treatment method prior to its discharge into waterways.
This is an Open Access article distributed under the terms of the Creative Commons Attribution Non-Commercial License (http://creativecommons. org/ licenses/by-nc/3.0/) which permits unrestricted non-commercial use, distribution, and reproduction in any medium, provided the original work is properly cited.
Received June 24, 2014 Accepted March 3, 2015

$\uparrow$ Corresponding author

Email: oramas.s@psu.ac.th

Tel: +66-7-428-6829 Fax: +66-7-442-9758

Copyright (C) 2015 Korean Society of Environmental Engineers 
Various physico-chemical and biological processes including activated carbon adsorption, membrane technology, evaporation, oxidation and biological degradation have been employed for the removal of phenols [15]. Among them, biological method is considered to be more attractive treatment option since it has high potential to eliminate phenols content at a low cost and is environmentally friendly. A number of different bacteria and white-rot fungi, such as Ralstonia sp., Pseudomonas putida [16, 17], Azotobacter vinelandii [18], Lentinula edodes [19], Phanerochaete chrysosporium [20], Geotrichum candidum [20, 21], and Trametes versicolor [22] have been shown to aerobically degrade many phenols found in olive mill wastewater (OMW). OMW usually contains high concentrations of phenols similar to POME. To minimize the effect of high concentrations of phenols, the OMW was usually diluted before biotreatment [23, 24]. However, it is considered as an unsustainable method since larger wastewater volume is generated. On the other hand, Ergül et al. [22] proposed that the high phenolic content of OMW can be effectively reduced by using an acclimated white-rot fungus Trametes versicolor FPRL $28 \mathrm{~A}$ INI. They found that about $78 \%$ of total phenols in the undiluted OMW were removed after this strain was consecutively acclimated in the different dilutions of OMW. The cell immobilization of white-rot fungus Phanerochaete chrysosporium was also applied to solve this problem. However, this approach was not successful for the undiluted OMW due to the very high concentration of phenols [25].

There are limited researches on the removal of phenols from POME. Recently, Limkhuansuwan and Chaiprasert [26] reported that free cells of Lactobacillus plantarum SFS.6 could degrade $34 \%$ of $33.64 \mathrm{mg} / \mathrm{L}$ phenols in treated POME. The low phenol removal efficiency could be due to the toxicity of POME to the bacterial cells, thus this study focused on the application of immobilized bacteria for phenol removal from the treated POME. To develop an effective bacterial inoculum, this study determined the ability of two phenol-degrading bacteria, Methylobacterium sp. NP3 and Acinetobacter sp. PK1 after immobilizing on EFBs. The mixed bacteria were found to be tolerant and specifically degrade phenol in concentrations of up to $5,000 \mathrm{mg} / \mathrm{L}$ while they were immobilized on silica [27]. However, the bacterial encapsulation in such matrix may be expensive for wastewater treatment while attachment immobilization on natural material such as EFBs is cheaper. In addition, the utilization of the abundant EFBs gives value-added to the palm oil mill wastes and is environmentally friendly thus making it is attractive for practical application. To increase the efficiency of the immobilized bacteria, three approaches, namely activation, acclimation, and combined activation and acclimation were applied. Prior to biodegradation, they were activated in a carbon free mineral medium (CFMM) containing phenol to induce/maintain phenol-degrading enzymes due to the absence of phenol during cell immobilization. Alternatively, they were acclimated by cultivating in diluted POME to minimize the toxicity of phenols in the undiluted POME. The combination of these two techniques by sequential activation in phenol-CFMM and acclimation in diluted POME was also performed. Moreover, the reusability of immobilized bacteria for POME treatment was evaluated.

\section{Materials and Methods}

\subsection{Treated POME Sample}

The treated POME sample was obtained from the wastewater treatment plant of a palm oil mill located in southern Thailand. The sample was collected from the final pond of a three series stabilization pond system and stored at $-20^{\circ} \mathrm{C}$ until used. The POME sample was prepared by filtration using cheesecloth to eliminate unwanted debris and was sterilized by autoclaving at $121^{\circ} \mathrm{C}$ for $15 \mathrm{~min}$ prior to use. The main characteristics of the treated POME are shown in Table 2.

\subsection{Preparation of Phenol Degrading Inoculum}

Mixed cultures of two bacterial strains, namely Methylobacterium sp. NP3 and Acinetobacter sp. PK1 were used for the biodegradation of phenols in a liquid CFMM or treated POME sample. The CFMM consisted of $3.0 \mathrm{~g} / \mathrm{L} \mathrm{NH}_{4} \mathrm{NO}_{3} ; 2.2 \mathrm{~g} / \mathrm{L} \mathrm{Na}_{2} \mathrm{HPO}_{4} ; 0.8 \mathrm{~g} / \mathrm{L} \mathrm{KH}_{2} \mathrm{PO}_{4}$; $0.1 \mathrm{~g} / \mathrm{L} \mathrm{MgSO} \cdot 7 \mathrm{H}_{2} \mathrm{O} ; 0.05 \mathrm{~g} / \mathrm{L} \mathrm{FeCl}_{3} \cdot 6 \mathrm{H}_{2} \mathrm{O}$ and $0.05 \mathrm{~g} / \mathrm{L} \mathrm{CaCl} \cdot 2 \mathrm{H}_{2} \mathrm{O}$ [28]. The inocula were prepared as previously mentioned in Khongkhaem et al. [27]. Briefly, each strain was cultivated independently in the liquid CFMM containing $0.4 \%$ glucose and was incubated on an orbital shaker at $200 \mathrm{rpm}$, room temperature for $72 \mathrm{~h}$. The cells were harvested by centrifugation at 8,000 rpm for $10 \mathrm{~min}$, washed twice and re-suspended in fresh CFMM containing $10 \mathrm{mg} / \mathrm{L}$ of phenol. The cell suspensions were incubated for $24 \mathrm{~h}$ at room temperature with $200 \mathrm{rpm}$ shaking to induce the formation of phenol-degrading enzymes. The induced-cells were harvested, washed and resuspended in fresh CFMM to a final $\mathrm{OD}_{578}$ of 1.0 (corresponding to approximately $10^{8} \mathrm{CFU} / \mathrm{mL}$ ) before they were mixed equally and used as an inoculum in the biodegradation experiment.

\subsection{Immobilization of Bacteria on EFBs}

The EFBs used as the immobilizing material are solid residues from palm oil extraction process obtained from a palm oil mill in Southern Thailand. The EFBs were cut into segments of about $2 \times 2.5 \times 2 \mathrm{~cm}^{3}$, oven-dried at $50^{\circ} \mathrm{C}$ for $24-48 \mathrm{~h}$ and autoclaved at $121^{\circ} \mathrm{C}$ for $20 \mathrm{~min}$ to eliminate the existing microorganisms prior to use. The surface area and total pore volume of the EFBs were analyzed by surface area analyzer (BelsorpII mini; BEL, Japan) and calculated according to Brunauer-Emmett-Teller (BET), Langmuir plot and Barrer-Joyner-Halenda (BJH). The immobilization of the cells was carried out by the attachment technique, in which $30 \mathrm{~mL}$ of bacterial inoculum in CFMM were added into a 250-mL Erlenmeyer flask containing $9 \mathrm{~g}$ of EFBs. The mixture of bacteria and EFBs residue were incubated at room temperature by shaking at $120 \mathrm{rpm}$. The bacteria were incubated along with the sterilized EFBs without an additional carbon source for various periods. With carbon starvation, the excess nitrogen $(0.91 \% \mathrm{~N}$ found in EFBs) is converted to protein and amino acid in the exopolysaccharide (EPS) which enhanced the cell surface hydrophobicity as well as increasing the attachment ability [29, 30].

To obtain bacteria well-attached to the surface of the EFBs, the production of bacterial exopolysaccharide was monitored daily by a modified Alcian blue adsorption assay of Vandevivere and 
Kirchman [31]. The immobilized cells materials were filtered and added to new vials containing $30 \mathrm{~mL}$ CFMM and $1 \%$ Alcian blue solution in $3 \%$ acetic acid ( $\mathrm{pH}=2.5$ ). The immobilized cells materials were mixed thoroughly by shaking at $80 \mathrm{rpm}$ for 20 min, and then they were removed. Subsequently, the measurement of the Alcian blue remaining in the solution was performed spectrophotometrically at $606 \mathrm{~nm}$ (UV-1601; Shimadzu, Japan). The amount of bacterial EPS produced was estimated by the decline of the Alcian blue dye due to its adsorption on EPS. The uninoculated EFBs were used as a negative control.

The bacterial attachment was visualized by a scanning electron microscope (FEI Quanta 400; FEI, USA). Initially, the immobilized cells materials were fixed with glutaraldehyde, dehydrated by sequential ethanol extraction, and dried by a critical point dryer. The samples were put on the stub then coated with gold before SEM analysis.

In addition, the number of phenol-degrading bacteria attached on the EFBs was analyzed by a plate count technique after the bacteria were extracted from the EFBs. The immobilized cells materials were rehydrated in a CFMM for $3 \mathrm{~min}$, sonicated (T780 ultrasonic bath; Elma, Germany) for $2 \mathrm{~min}$, and shaken vigorously on a vortex mixer for another 2 min (a method modified from Pattanasupong et al. [32]).These procedures were repeated twice. Subsequently, the suspensions of the cells were determined for the number of bacteria on glucose-CFMM. The samples were measured in duplicate.

\subsection{Effect of Phenol Concentrations on Suspended and Immobilized Bacteria}

Immobilized bacteria were tested for their ability to degrade different initial phenol concentrations. The biodegradation experiment was conducted in a 22-mL vial containing $5 \mathrm{~mL}$ CFMM with the phenol concentrations in the range of $10-5,000 \mathrm{mg} / \mathrm{L}$ and $0.5 \mathrm{~g}$ immobilized cells materials. For suspended bacteria, $4 \mathrm{~mL}$ CFMM containing phenol and $1 \mathrm{~mL}$ cell suspension were added into the vial. The number of bacteria in both systems was similar. The samples were incubated at room temperature and shaken at $120 \mathrm{rpm}$. The sampling was done every $24 \mathrm{~h}$ for $24-120 \mathrm{~h}$ to determine the remaining phenol. The efficiency of the phenol degradation was presented as the \% degradation and the degradation rate constant $\left(\mathrm{h}^{-1}\right)$. The controls, consisting of heat-killed cells and uninoculated EFBs, were used to represent the adsorption of phenol on bacterial cells and on the material. The experiment was done in triplicate.

\subsection{Phenol Degradation in Treated POME by Activated and/or Acclimated Bacteria}

To induce/maintain phenol-degrading enzymes after cell immobilization, the immobilized bacteria were activated in a liquid CFMM containing $10 \mathrm{mg} / \mathrm{L}$ phenol for $24 \mathrm{~h}$ before the POME treatment. Alternatively, they were consecutively transferred to $25 \%$ diluted POME for $120 \mathrm{~h}$ and 50\% diluted POME for another $120 \mathrm{~h}$ for cell acclimatization to the phenols present in POME. The combination of these two techniques which were $24 \mathrm{~h}$ activation in phenol-CFMM and then $240 \mathrm{~h}$ acclimation in each $25 \%$ and $50 \%$ diluted POME was also studied. The treatment of the POME was conducted in a $250 \mathrm{~mL}$ Erlenmeyer flask containing $30 \mathrm{~mL}$ POME and $9 \mathrm{~g}$ immobilized cells materials. Samples were incubated at room temperature and shaken at $120 \mathrm{rpm}$ for $168 \mathrm{~h}$. Sampling was done every $24 \mathrm{~h}$ for determining the remaining phenols and other characteristics of the treated POME. The controls consisted of non-activated and non-acclimated immobilized bacteria. The experiment was done in triplicate.

\subsection{Reusability of Immobilized Bacteria}

The reusability of immobilized bacteria was examined to assess whether they could be applied repeatedly. After the first application in phenol-CFMM or in treated POME, the used immobilized bacteria were separated from the liquid content and reused for further treatment under similar conditions. Their efficiency to remove phenol(s) in each application cycle was compared.

\subsection{Analysis of Treated POME and Phenols}

The following characteristics of the treated POME were analyzed according to the Standard Methods for the Examination of Water and Wastewater [33]: pH; COD; total nitrogen; total phosphorus; oil and grease; phenols and color. The phenols were determined by a standard colorimetric assay. This was done with 4-aminoantipyrine in the presence of ammonium hydroxide and potassium ferricyanide which produced a coloured antipyrine dye that was measured spectrophotometrically at $500 \mathrm{~nm}$ (UV 1601; Shimadzu, Japan).

\section{Results and Discussion}

\subsection{Formation of EPS by Strain NP3 and PK1 during Attachment on EFBs}

An attachment technique was applied for the immobilization of Methylobacterium sp. NP3 and Acinetobacter sp. PK1 on the EFBs. The complex structure and high porosity of EFBs with a total pore volume of $0.44 \mathrm{~cm}^{3} / \mathrm{g}$ and BET surface area of $4.17 \mathrm{~m}^{2} / \mathrm{g}$ makes it a suitable support for cell immobilization. EFBs had a similar total pore volume but much lower specific surface area compared to the commercial absorbent such as activated carbon $\left(0.43 \mathrm{~cm}^{3} / \mathrm{g}\right.$ and 907.8-1,100 $\mathrm{m}^{2} / \mathrm{g}$, respectively) [34, 35].

It was necessary to ensure stable cell adhesion to the solid surface of the EFBs. To assess this, the production of EPS during the attachment process was determined by the decrease in absorbance of Alcian blue dye in the supernatant measured spectrophotometrically at $\mathrm{A}_{606}$. There was no change in the $\mathrm{A}_{606}$ detected in the uninoculated control materials throughout the course of the study, ensuring no sorption of this dye on the EFBs. In addition, the EPS formation was not present in the monoculture and mixed culture (strain NP3 and PK1) immobilization during the first three days of incubation (Fig. 1). After 3 days, both the monoculture and mixed cultures were able to produce much EPS as seen from the rapid decrease in $\mathrm{A}_{606}$ of the Alcian blue. A longer incubation led to greater EPS synthesis in all samples. However, the highest rate of EPS production was obtained when two strains were mixed together obtaining a maximum 85\% yield of EPS after 6 days incubation. In accord with earlier findings, the mixed culture of S. thermophilus 13a and L. bulgaricus exhibited higher EPS synthe- 


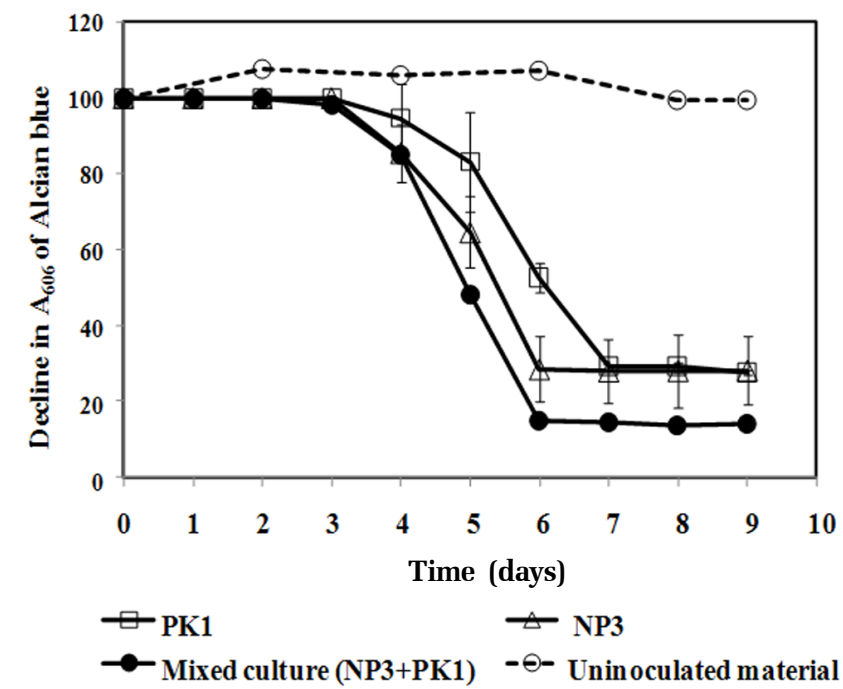

Fig. 1. Production of exopolysaccharides (EPS) measured by the decline in absorbance of Alcian Blue at $606 \mathrm{~nm}$ after incubating mono and mixed culture of strain NP3 and PK1 with EFB. The sterilized EFB without cells (Uninoculated material) was used as control.

sizing activity compared to the single strain due to a mutual stimulation of cell metabolism [36].

The bacterial EPS is essential for biofilm formation, aggregating and sheathing the cells as well as protecting them against adverse conditions [37]. SEM photomicrographs revealed that bacteria produced EPS fibers in cells adhering to the surfaces and to other microorganisms (Fig. 2). From the results in this section, mixed cultures of the strains NP3 and PK1 were incubated along with EFBs for 6 days to obtain a strong attachment. These were used for further biodegradation tests.

\subsection{Effect of Phenol Concentration on Activity of Strain NP3 and PK1}

Phenol, the simplest member of the family of phenols, was used in this study as a representative of this compound group to assess its impact on Methylobacterium sp. NP3 and Acinetobacter sp. PK1. The capacities of immobilized and suspended bacteria to degrade phenol were compared in liquid CFMM containing different initial phenol concentrations ranging from 10 to 5,000 mg/L. In the control samples with killed-cells and EFBs only, the reduction of the phenol was very low ( $\leq 5 \%)$. Thus,the loss of phenol by abiotic processes was negligible.

The immobilized bacteria showed greater degradation efficiency and degradation rate constant $(k)$ than that of suspended bacteria, at all phenol concentrations, except when the concentration was below $30 \mathrm{mg} / \mathrm{L}$ (Fig. 3(a), (b)). On the other hand, an inhibitory effect was observed in the suspended bacteria when the phenol concentration increased as seen from the decreased degrading efficiency and rate. These results indicated that suspended bacteria were inhibited by elevated concentrations of phenol, while the immobilized bacteria were more tolerant of phenol of up to 5,000 $\mathrm{mg} / \mathrm{L}$. This difference was attributed to the fact that the cells of the immobilized bacteria were protected of against the toxicity of phenol through their biofilm and immobilizing support. The bacterial biofilm and organic material can act as a buffer in shielding bacteria from high exposure to high concentrations of phenols, adsorbing and slowly releasing them for bacterial degradation [38]. Our results corresponded to previous studies of Khongkhaem et al. [27], Ying et al. [39] and Ahmad et al. [40]. They reported that better phenol degradation activity was achieved when a mixture of Methylobacterium sp. NP3 and Acinetobacter sp. PK1, Acinetobacter sp. strain PD12 or Acinetobacter sp. strain AQ5NOL1 were immobilized in silica, polyvinyl alcohol (PVA) or gellan gum, respectively. However, the EFBs used in this study were palm oil mill waste and considered as inexpensive compared to other immobilizing materials.

Nonetheless, one major disadvantage of using immobilized cells is the mass transfer limitation involved in substrate diffusion to the cells [41]. This could explain why the immobilized bacteria had lower degradation activity at low phenol concentrations compared to suspended bacteria. In addition, the $k$ values for immobilized bacteria in this study (0.01-0.47 $\left.\mathrm{h}^{-1}\right)$ (Fig. 3(b)) were lower than those reported by Ying et al. [39] $\left(0.65-1.38 \mathrm{~h}^{-1}\right)$. This may be because the ranges of initial phenol concentrations used were different and/or our experiment had lower cells density attached to EFBs $\left(1.13 \mathrm{mg}\right.$ cells $\mathrm{L}^{-1}$ phenol-CFMM), while much higher cells were entrapped by PVA (24.6 mg cells $\mathrm{L}^{-1}$ ).
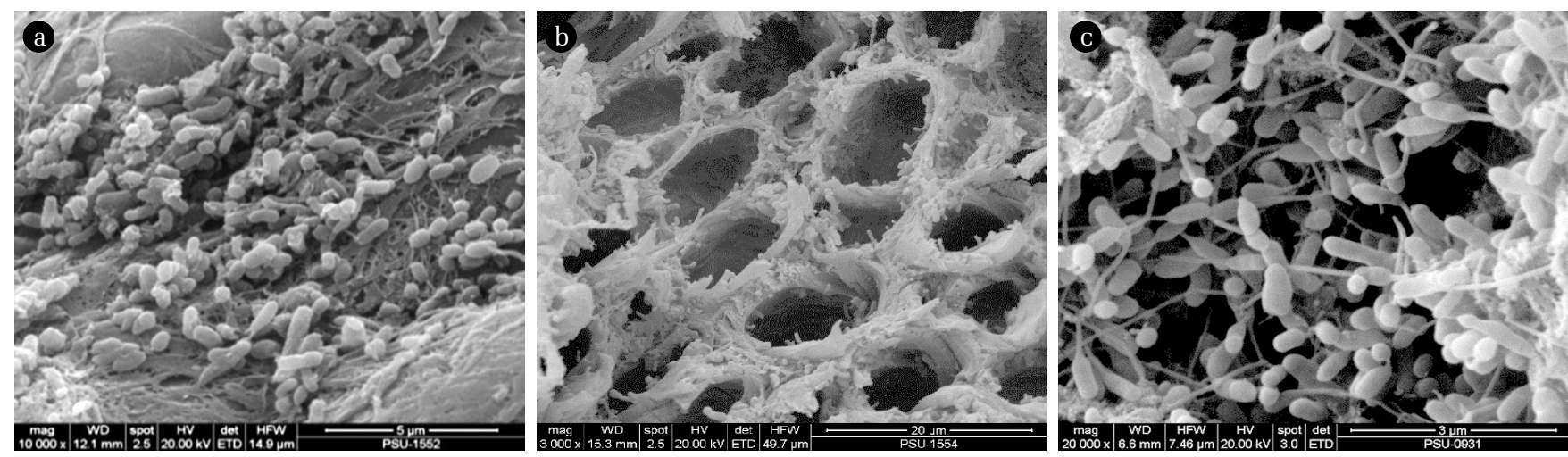

Fig. 2. SEM of mixed bacterial cells (strain NP3+PK1) attached to surface (a) and to interconnected pores (b) of EFB and network-like EPS structures adhered to EFB surfaces and to other microorganisms (c) after 6 days incubation. 

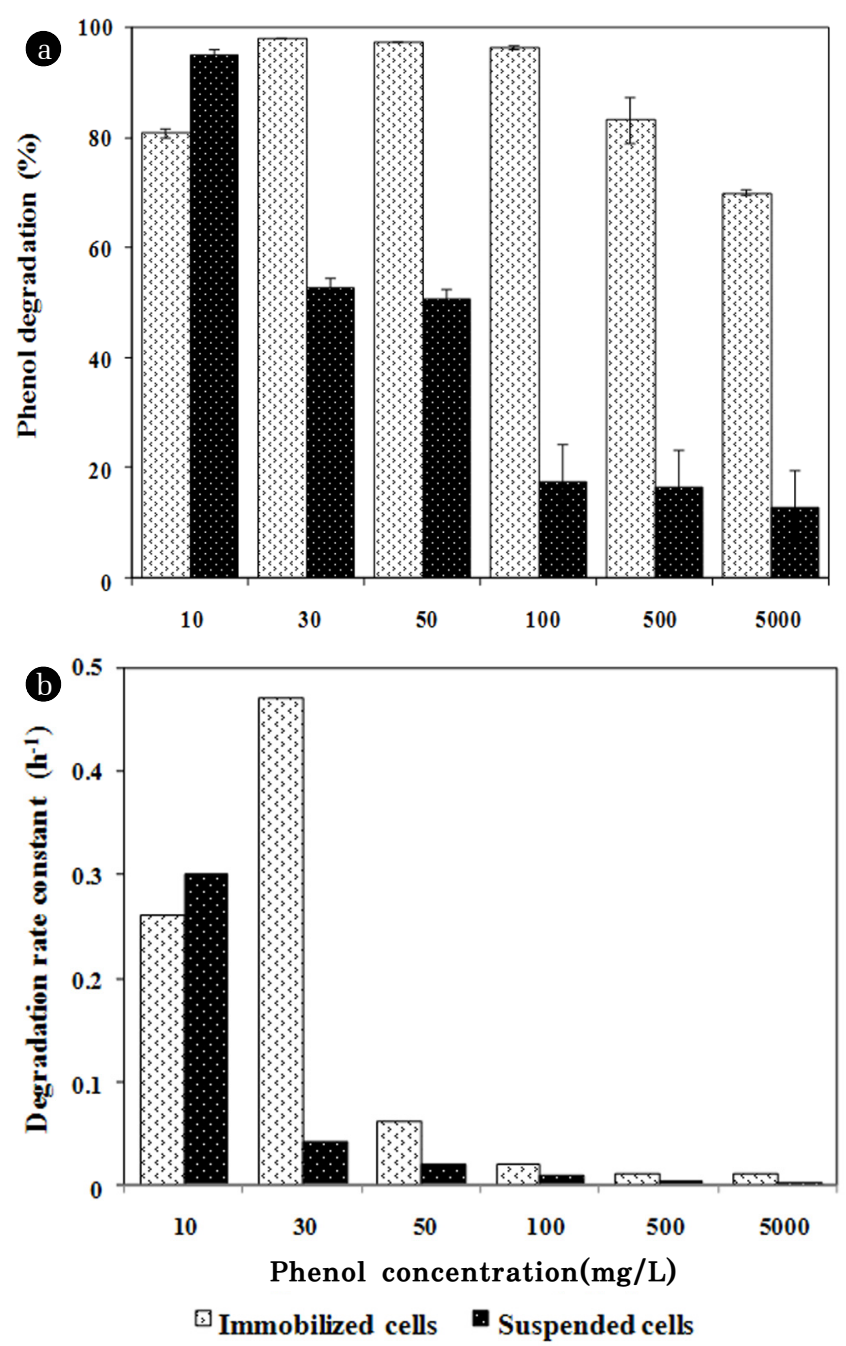

Fig. 3. Phenol degradation (a) and degradation rate constant (b) after $24 \mathrm{~h}(10$ and $30 \mathrm{mg} / \mathrm{L}), 72 \mathrm{~h}(50 \mathrm{mg} / \mathrm{L}), 96 \mathrm{~h}(100 \mathrm{mg} / \mathrm{L})$ and $120 \mathrm{~h} \mathrm{(500} \mathrm{and} \mathrm{5,000} \mathrm{mg/L)} \mathrm{of} \mathrm{incubation} \mathrm{using} \mathrm{immobilized}$ and suspended bacteria.

\subsection{Removal of Phenols from Treated POME by Activated and/or Acclimated Immobilized Bacteria}

Three approaches were evaluated in order to enhance the phenols degrading efficiency of the immobilized bacteria. These were: (1) cell activation; (2) cell acclimation; and a combination of (1) and (2). Table 1 shows a comparison of the aforementioned techniques and the control (non-activation and non-acclimation) for phenols removal from the treated POME. The results showed that cell activation, acclimation and a combination of the two methods together were able to improve almost double the phenol reduction of the control sample (Table 1). Comparing between these three methods, the application of either activation method only or a combination of activation and acclimation method had similar result with $63.4 \%$ and $65.0 \%$ phenols removal from the total phenols of $33 \mathrm{mg} / \mathrm{L}$ in the treated POME. However, the acclimation method only provided less efficiency with a phenol removal of $53.5 \%$.
The removal efficiencies of our immobilized bacteria were higher than those studied by Limkhuansuwan and Chaiprasert [26]. They found that free cells of Lactobacillus plantarum SF5.6 was able to remove $34.0 \%$ of the $33.64 \mathrm{mg} / \mathrm{L}$ phenols in the treated POME.

During immobilization process, the bacteria might lose their phenol degradability due to the absence of phenol. An activation of the attached bacteria by providing them with phenol-CFMM could therefore stimulate the induction/maintenance of the phenols-degrading enzymes needed for biodegradation. In the previous studies, the bacterial and fungal acclimation in diluted wastewater containing phenols was found to efficiently remove phenols in undiluted wastewater. These include Pseudomonas putida ATCC 17484 [42] and white-rot fungus Trametes versicolor [22]. Kumar and Mohanty [43] reported that mixed microbial culture isolated from the sludge of effluent treatment plant of a refinery could biodegrade up to $750 \mathrm{mg} / \mathrm{L}$ of phenol after acclimatization. Our results also corresponded to those of Lu et al. [44]. They found that white-rot fungus Phanerochaete chrysosporium was able to remove over $84 \%$ of phenols from coking wastewater and $80 \%$ of COD after activation with phenol and acclimation with 50\% diluted coking wastewater.

Accordingly, activation and/or acclimation process could be efficient methods for the improvement of the degradation efficiency of phenols-degrading bacteria. However, activation process seemed to be more attractive since it was convenient and less time-consuming

Table 1. Removal of Phenols from Treated POME by Activated and/or Acclimated Immobilized Bacteria Compared to Control

\begin{tabular}{|c|c|}
\hline Technique & phenols degradation (\%) \\
\hline Non-activation \& non-acclimation & $35.0 \pm 1.4^{\mathrm{a}}$ \\
\hline Acclimation & $53.5 \pm 1.5^{\mathrm{b}}$ \\
\hline Activation & $63.4 \pm 0.4^{\mathrm{C}}$ \\
\hline Activation and acclimation & $65.0 \pm 4.7^{\mathrm{C}}$ \\
\hline
\end{tabular}

*An initial phenols concentration of $33 \mathrm{mg} / \mathrm{L}$ was detected in the treated POME. Phenols degradation was determined after 7-d incubation by comparing with the initial phenols concentration. Values given are average of three samples \pm standard deviation. Comparisons between four techniques are significantly different (LSD, $\mathrm{P}<0.05$ ) if designed with different-letters.

Table 2. Characteristics of the Sterilized POME Before and After Treatment with Activated Immobilized Bacteria After 7 days of Incubation

\begin{tabular}{lcc}
\hline \multicolumn{1}{c}{ Parameter } & $\begin{array}{c}\text { Before } \\
\text { treatment }\end{array}$ & $\begin{array}{c}\text { After } \\
\text { treatment }\end{array}$ \\
\hline $\mathrm{pH}$ & 8.2 & 7.9 \\
$\mathrm{COD}(\mathrm{mg} / \mathrm{L})$ & $10,296.0$ & $1,355.0$ \\
Total nitrogen (mg/L) & 210.0 & 64.0 \\
Total phosphorus (mg/L) & 17.2 & 16.2 \\
Oil and grease (mg/L) & 30.0 & 5.0 \\
Phenols (mg/L) & 33.0 & 12.1 \\
Color $(\%)$ & 100.0 & 75.0 \\
No. of phenol-degrading bacteria on EFB & 23.0 & 48.0 \\
$\left(\times 10^{9} \mathrm{CFU} / \mathrm{g}\right)$ & & \\
No. of phenol-degrading bacteria in POME & - & 20.0 \\
$\left(\times 10^{9} \mathrm{CFU} / \mathrm{mL}\right)$ & & \\
\hline
\end{tabular}

-: Not detected. 
for application. It was found that $\mathrm{pH}$ of the treated POME slightly decreased after treated with activated immobilized bacteria. They also were able to reduce $86.8 \%$ COD, $70 \%$ total nitrogen, $5.8 \%$ total phosphorus, $83.3 \%$ oil and grease, and $25 \%$ color (Table 2). The number of phenol-degrading bacteria on EFBs was $2.3 \times 10^{10} \mathrm{CFU} / \mathrm{g}$ EFBs at the beginning and increased to $4.8 \times 10^{10} \mathrm{CFU} / \mathrm{g}$ EFBs after 7 days incubation. In the treated POME, $2.0 \times 10^{10} \mathrm{CFU} / \mathrm{mL}$ phenol-degrading bacteria was found at the end of study. This was indicated that the organic content and other nutrients available in EFBs as well as in treated POME could support bacterial growth. The attached bacteria present on EFBs were effective to further remove phenols as seen from their ability to be reused (Fig. 4). Based on this result, the activated immobilized cells were utilized for reusability test in the next section.

\subsection{Reusability of Activated Immobilized Bacteria for Phenol (s) Degradation}

The stability of Methylobacterium sp. NP3 and Acinetobacter sp. PK1 immobilized by EFBs was assessed in several consecutive biodegradation of phenol(s). The ability of cells to degrade phenol(s) after repeated use was determined. The experiments were performed by incubating the activated immobilized bacteria with liquid CFMM containing phenol or with treated POME separately. In liquid CFMM, the immobilized bacteria were able to completely remove all phenol (33 mg/L) after $24 \mathrm{~h}$ incubation (Fig. 4). Although, the SEM micrographs showed that there were some changes in the surface of the EFBs and the density of the cells after 5 repeated cycles (Fig. 5(a), (b)). The bacterial activity remained the same throughout application over ten cycles.

Unlike in phenol-CFMM, various kinds of phenols and other organic compounds were present in the treated POME. A lower degradation of phenols in POME might be due to the effect of these components on bacterial activity and/or the competition of carbon source from various organic compounds. About $64.5 \%$ to $68.5 \%$ of the total phenols $(33 \mathrm{mg} / \mathrm{L})$ in the treated POME were

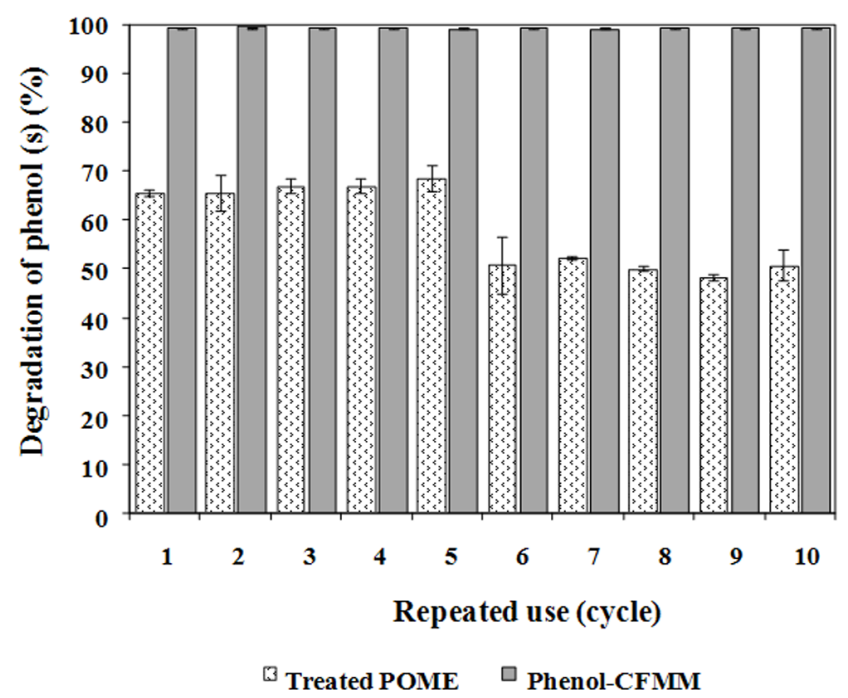

Fig. 4. Reusability of activated immobilized bacteria for biodegradation of $33 \mathrm{mg} / \mathrm{L}$ phenol(s) in liquid CFMM and in treated POME.
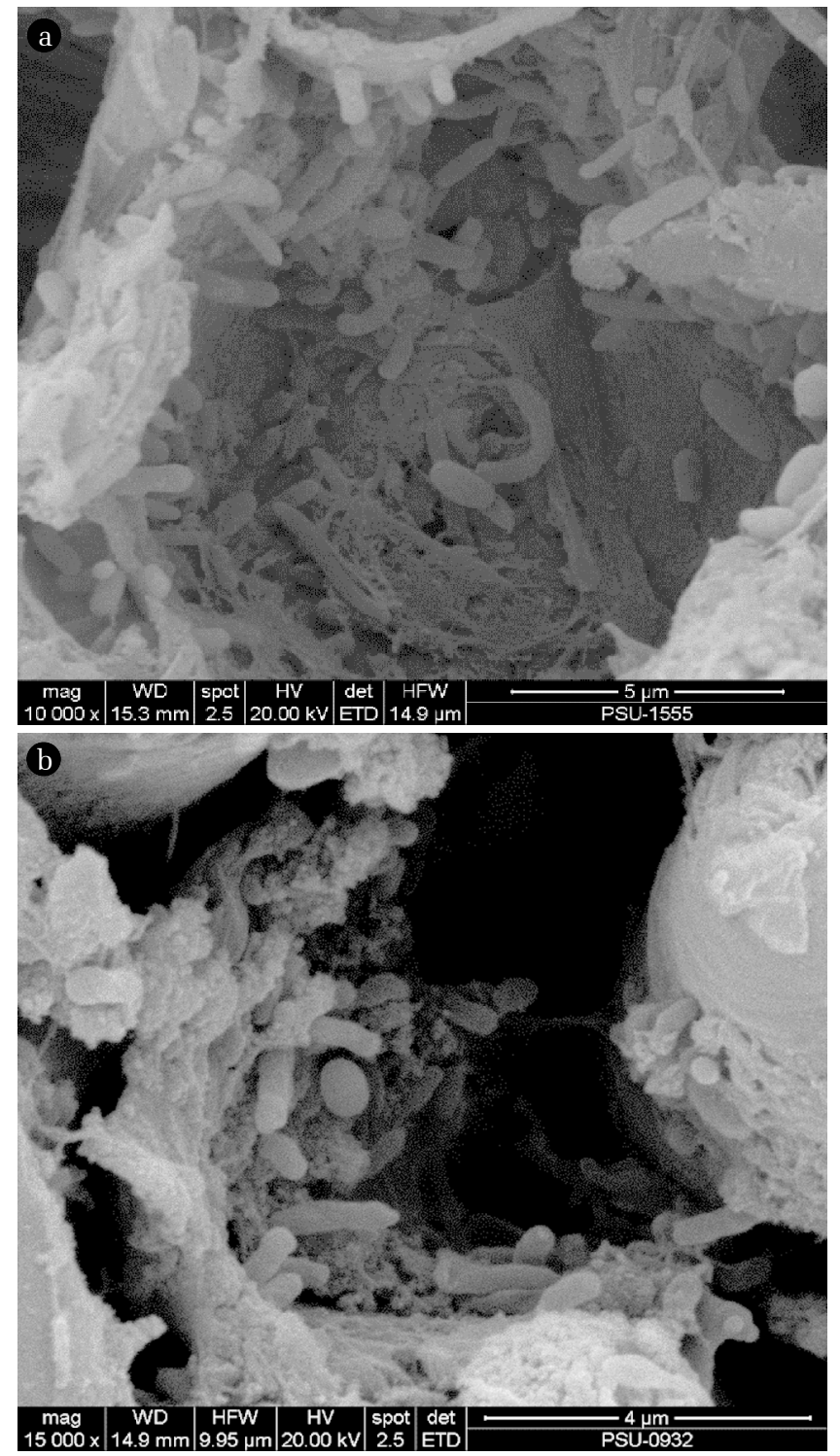

Fig. 5. Changes in EFB surface and number of immobilized bacteria explored by SEM before (a) and after (b) 5-cycle of repeated use.

removed after 7 days incubation with applications over five cycles. Then the degrading efficiency was reduced by $15.2 \%$ to $16.2 \%$ by applications over six to ten cycles (Fig. 4). This indicated that the activated immobilized bacteria could maintain their phenol-degrading activity throughout each application and could be reused for at least 10 cycles. The reduction of bacterial activity in the treated POME after applications over five cycles might result from the enzyme inactivation by some phenols components [45] in the treated POME.

In addition, the immobilized bacteria could be stored at $4^{\circ} \mathrm{C}$ for 4 weeks and maintain their stable phenol degrading activity. These results suggested that the immobilized bacteria on the EFBs had a potential for practical application in the treatment of wastewater contaminated with phenols. 


\section{Conclusions}

The attachment immobilization of Methylobacterium sp. NP3 and Acinetobacter sp. PK1 on EFBs residue were facilitated by their EPS structures. This immobilization improved bacterial tolerance to phenol in CFMM up to 5,000 $\mathrm{mg} / \mathrm{L}$ and the immobilized bacteria degraded phenol more efficiently than suspended bacteria. However, the best way to enhance the efficiency of these immobilized bacteria could be done by activating them in a CFMM containing phenol for $24 \mathrm{~h}$ before their utilization. This process was convenient and efficient strategy for enhancing the degradability and stability of phenol-degrading bacteria as seen from their efficiency to remove phenols from treated POME (63.4\%) and their ability to be reused.

Findings of this study clearly showed the potential use of the EFBs-immobilized bacteria as an inoculum for the subsequent aerobic post-treatment of previously treated POME from the anaerobic treatment systems. Further study can be done to develop a large-scale bioreactor employing the immobilized bacteria with continuous operation. This is considered to be practical and economical for its application in the real wastewater treatment plant of palm oil mills. Besides, the immobilized bacteria might be utilized for the treatment of various kinds of phenols present in other industrial effluents.

\section{Acknowledgements}

This research was supported by Prince of Songkla University through Researcher Development Grant (Contract no. ENV530101S) and the Graduate School funding. The authors wish to thank the Faculty of Environmental Management and the Center of Excellence on Hazardous Substance Management (HSM) at Prince of Songkla University for kindly providing the laboratory facilities. We are grateful to Piyamart Khongkhaem for her help with bacterial cultivation technique.

\section{References}

1. Rupani PF, Singh RP, Ibrahim MH, Esa N. Review of current palm oil mill effluent (POME) treatment methods: Vermicomposting as a sustainable practice. World Appl. Sci. J. 2010;10:1190-1201.

2. Chavalparit O, Rulkens WH, Mol APJ, Khaodhair S. Options for environmental sustainability of the crude palm oil industry in Thailand through enhancement of industrial ecosystems. Environ. Dev. Sustain. 2006;8:271-287.

3. Ahmad AL, Ismail S, Bhatia S. Water recycling from palm oil mill effluent (POME) using membrane technology. Desalination 2003;157:87-95

4. Alam MZ, Ameem ES, Muyibi SA, Kabbashi NA. The factors affecting the performance of activated carbon prepared from oil palm empty fruit bunches for adsorption of phenol. Chem. Eng. J. 2009;155:191-198.

5. Cordova-Rosa SM, Dams RI, Cordova-Rosa EV, Radetski MR, CorrêaAXR, Radetski CM. Remediation of phenol-con- taminated soil by a bacterial consortium and Acinetobacter calcoaceticus isolated from an industrial wastewater treatment plant. J. Hazard. Mater. 2009;164:61-66.

6. Kaewmai R, H-Kittikun A, Suksaroj C, Musikavong C. Alternative technologies for the reduction of greenhouse gas emissions from palm oil mills in Thailand. Environ. Sci. Tech. 2013;47:12417-12425.

7. Wu YT, Mohammad WA, Jahim MJ, Anuar N. A holistic approach to managing palm oil mill effluent (POME): Biotechnological advances in the sustainable reuse of POME. Biotechnol. Adv. 2009;27:40-52.

8. Ramos-Cormenzana A, Juarez-Jimenez B, Garcia-Pareja MP. Antimicrobial activity of olive mill wastewaters (alpechin) and biotransformed olive oil mill wastewater. Int. Biodeterior. Biodegradation 1996;38:283-290.

9. Kılıç NK, Karacakaya P, Duygu E, Dönmez G. Biodegradation of phenol by Synechocystis sp. in media including triacontanol hormone. Water Environ. J. 2012; 26:94-99.

10. Hernandez JE, Edyvean RGJ. Inhibition of biogas production and biodegradability by substituted phenolic compounds in anaerobic sludge. J. Hazard. Mater. 2008;160:20-28.

11. Neoh CH, Lam CY, Lim CK, Yahya A, Ibrahim Z. Decolorization of palm oil mill effluent using growing cultures of Curvularia clavata. Environ. Sci. Pollut. Res. 2014;21:4397-4408.

12. Tuck KL, Hayball PJ. Major phenolic compounds in olive oil: metabolism and health effects. J. Nutr. Biochem. 2002;13: 636-644.

13. D’Annibale A, Casa R, Pieruccetti F, Ricci M, Marabottini R. Lentinula edodes removes phenols from olive-mill wastewater: impact on durum wheat (Triticum durum Desf.) germinability. Chemosphere 2004;54:887-894.

14. Shirzad-Sibon M, Jafari S-J, Farrokhi M, Yang JK. Removal of Phenol from Aqueous Solutions by Activated Red Mud: Equilibrium and Kinetics Studies. Environ. Eng. Res. 2013;18: 247-252.

15. Said M, Ahmad A, Mohammad AW. Removal of phenol during ultrafiltration of palm oil mill effluent (POME): Effect of $\mathrm{pH}$, ionic strength, pressure and temperature. Der. Pharma. Chemica. 2013;5:190-196.

16. Di Gioia D, Bertin L, Fava F, Marchetti L. Biodegradation of hydroxylated and methoxylated benzoic, phenylacetic and phenylpropenoic acids present in olive mill wastewaters by two bacterial strains. Res. Microbiol. 2001;152:83-93.

17. Di Gioia D, Fava F, Bertin L, Marchetti L. Biodegradation of synthetic and natural occurring mixtures of mono-cyclic aromatic compounds present in olive mill wastewaters by two aerobic bacteria. Appl. Microbiol. Biotechnol. 2001;55:619-626.

18. Piperidou CI, Chaidou CI, Stalikas CD, Soulti K, Pilidis GA, Balis C. Bioremediation of olive oil mill wastewater: chemical alterations induced by Azotobacter vinelandii. J. Agric. Food Chem. 2000;48:1941-1948.

19. Lakhtar H, Ismaili-Alaoui M, Philippoussis A, Perraud-Gaime I, Roussos S. Screening of strains of Lentinula edodes grown on model olive mill wastewater in solid and liquid state culture for polyphenol biodegradation. Int. Biodeterior. Biodeg. 2010;64:167-172. 
20. García GI, Jimenez Pena PR, Bonilla Venceslada JL, Martín MA, Santos MM, Gómez ER. Removal of phenol compounds from olive mill wastewater using Phanerochaetechrysosporium, Aspergillus niger, Aspergillus terreus and Geotrichum candidum. Process. Biochem. 2000;35:751-758.

21. Asses N, Ayed L, Bouallagui H, Sayadi S, Hamdi M. Biodegradation of different molecular-mass polyphenols derived from olive mill wastewaters by Geotrichum candidum. Int. Biodeterior. Biodeg. 2009;63:407-413.

22. Ergül FE, Sargın S, Öngen G, Sukan FV. Dephenolisation of olive mill wastewater using adapted Trametes versicolor. Int. Biodeterior. Biodeg. 2009;63:1-6.

23. Robles A, Lucas R, de Cienfuegos GA, Gálvez A. Biomass production and detoxification of wastewaters from the olive oil industry by strains of Penicillium isolated from wastewater disposal ponds. Bioresour. Technol. 2000;74:217-221.

24. Öngen G, Güngör G, Kanberoglu B. Decolorisation and dephenolisation potential of selected Aspergillussection NigristrainsAspergillus tubingensis in olive mill wastewater. World J. Microbiol. Biotechnol. 2007;23:519-524.

25. AhmadiM, Vahabzadeh F, Bonakdarpour B, Mehranian M, Mofarrah E. Phenolic removal in olive oil mill wastewater using loofah-immobilized Phanerochaete chrysosporium. World J. Microbiol. Biotechnol. 2006;22:119-127.

26. Limkhuansuwan V, Chaiprasert P. Decolorization of molasses melanoidins and palm oil mill effluent phenolic compounds by fermentative lactic acid bacteria. J. Environ. Sci. 2010;22: 1209-1217.

27. Khongkhaem P, Intasiri A, Luepromchai E. Silica-immobilized Methylobacterium sp. NP3 and Acinetobacter sp. PK1 degrade high concentrations of phenol. Lett. Appl. Microbiol. 2011;52: 448-455.

28. Kasuga K, Nojiri H, Yamane H, Kodama T, Omori T. Cloning and characterization of the genes involvedin the degradation of dibenzofuran by Terrabacter sp. strain DBF63. J. Ferment. Bioeng. 1997;84:387-399.

29. Durmaz B, Sanin FD. Effect of carbon to nitrogen ratio on the composition of microbial extracellular polymers in activated sludge. Water Sci. Technol. 2001;44:221-229.

30. Sanin SL, Sanin FD, Bryers JD. Effect of starvation on the adhesive properties of xenobiotic degrading bacteria. Process. Biochem. 2003;38:909-914.

31. Vandevivere P, Kirchman DL. Attachment stimulate exopolysaccharide synthesis by a bacterium. Appl. Environ. Microbiol. 1993;59:3280-3286.

32. Pattanasupong A, Nagase H, Sugimoto E, et al. Degradation of Carbendazim and 2-4 dichlorophenoxyacetic acid by immobilized consortium on loofa sponge. J. Biosci. Bioeng.
2004;98:28-33.

33. APHA, AWWA, WEF. Standard methods for the examination of water and wastewater. 21th ed. Washington DC: American Public Health Association (APHA); 2005.

34. Lu Q, Sorial GA. Adsorption of phenolics on activated carbon-impact of pore size and molecular oxygen. Chemosphere 2004;55:671-679.

35. Ng YL, Yan R, Chen XG, et al. Use of activated carbon as a support medium for $\mathrm{H} 2 \mathrm{~S}$ biofiltration and effect of bacterial immobilization on available pore surface. Appl. Microbiol. Biotechnol. 2004;66:259-265.

36. Simova ED, Frengova GI, Beshkova DM. Exopolysaccharides produced by mixed culture of yeast Rhodotorula rubra GED10 and yogurt bacteria (Streptococcus thermophilus 13a+ Lactobacillus bulgaricus 2-11). J. Appl. Microbiol. 2004;97: 512-519.

37. Rosche B, Li XZ, Hauer B, Schmid A, Buehler K. Microbial biofilms: a concept for industrial catalysis? Trends Biotechnol. 2009;27:636-643.

38. Kindzierski WB, Fedorak PM, Gray MR, Hrudey SE. Activated carbon and synthetic resins as support material for mathanogenic phenol-degrading consortia-comparison of phenol-degrading activities. Water Environ. Res. 1995;67:108-117.

39. Ying W, Ye T, Bin H, Zhao HB, Bi JN, Cai BL. Biodegradation of phenol by free and immobilized Acinetobacter sp. strain PD12. J. Environ. Sci. 2007;19:222-225.

40. Ahmad SA, Shamaan NA, Arif NM, Koon GB, Shukor MYA, Syed MA. Enhanced phenol degradation by immobilized Acinetobacter sp. strain AQ5NOL. World J. Microbiol. Biotechnol. 2012;28:347-352.

41. Wang X, Gai Z, Yu B, et al. Degradation of carbazole by microbial cells immobilized in magnetic gellan gum gel beads. Appl. Environ. Microbiol. 2007;73:6421-6428.

42. González G, Herrera G, García MT, Pena M. Biodegradation of phenolic industrial wastewater in a fluidized bed bioreactor with immobilized cells of Pseudomonas putida. Bioresour. Technol. 2001;80:137-142.

43. Kumar H, Mohanty K. Kinetic modeling of phenol biodegradation by mixed microbial culture in static batch mode. Asian J. Water Environ. Pollut. 2012;9:19-24.

44. Lu Y, Yan L, Wang Y, Zhou S, Fu J, Zhang J. Biodegradation of phenolic compounds from coking wastewater by immobilized white rot fungus Phanerochaete chrysosporium. J. Hazard. Mater. 2009;165:1091-1097

45. Diao M, Ouédraogo N, Baba-Moussa L, et al. Biodepollution of wastewater containing phenol compounds from leather industry by plant peroxidases. Biodegradation 2011;22:389-396. 